\title{
Evaluation of Chromium and Manganese levels in sports supplements using graphite furnace atomic absorption spectrometry
}

\author{
Avaliação do teor de Cromo e Manganês em suplementos \\ esportivos por meio de espectrometria de absorção \\ atômica em forno de grafite
}

Thalles Pedrosa LISBOA 1 (D) 0000-0003-0057-025X
Leonã da Silva FLORES² (D) 0000-0002-1092-8182
Charlane Cimini CORREA ${ }^{2}$ (DD) 0000-0002-7113-8870
Rafael Arromba de SOUSA 1 (D) 0000-0002-4520-4838

A B S T R A C T

\section{Objective}

In this paper, we studied three different types of ordinary sports supplements containing whey protein: whey protein-based ones, hypercaloric ones, and protein bars.

\section{Methods}

A sample preparation procedure was studied employing microwave-assisted wet digestion in order to determine the Chromium and Manganese levels by graphite furnace atomic absorption spectrometry.

\section{Results}

The developed methods have presented good accuracy (recoveries in the range of 90\% to 109\%) and precision (Relative standard deviation $<8 \%$ ). Although an adequate detectability was obtained (50ng g ${ }^{-1}$ for Manganese

\footnotetext{
1 Universidade Federal de Juiz de Fora, Departamento de Química, Grupo Baccan de Química Analítica. R. José Lourenço Kelmer, s/n., Campus Universitário, São Pedro, 36036-900, Juiz de Fora, MG, Brasil. Correspondence to: RA SOUSA. E-mail: <rafael.arromba@ufjf.edu.br>

2 Universidade Federal de Juiz de Fora, Departamento de Química, Grupo de Pesquisa em Química de Materiais Porosos. Juiz de Fora, MG, Brasil.

Support: Fundação de Amparo à Pesquisa do Estado de Minas Gerais (Process no CEX-APQ-02056-14).

Article elaborated from dissertation by TP LISBOA, entitled "Determinação de micronutrientes minerais em amostras de suplemento alimentar por espectrometria de absorção atômica". Universidade Federal de Juiz de Fora; 2016.
}

How to cite this article

Lisboa TP, Flores LS, Correa CC, Sousa RA. Evaluation of Chromium and Manganese levels in sports supplements using graphite furnace atomic absorption spectrometry. Rev Nutr. 2020;33:e190141. http://dx.doi.org/10.1590/1678-9 865202033 e190141 
and $65 \mathrm{ng} \mathrm{g}^{-1}$ for Chromium), the sample preparation method was also adequate to inductively coupled plasma mass spectrometry analysis. The method was applied to 26 commercial samples, in which the Chromium concentrations were in the range between 0.22 and $1.0 \mu \mathrm{g} \mathrm{g}^{-1}$ and the Manganese concentrations varied from 2.0 to $37 \mu \mathrm{g} \mathrm{g}^{-1}$.

\section{Conclusion}

The results obtained by atomic absorption for both analytes were in agreement with those obtained by mass spectrometry. In addition, some samples presented concentrations of Chromium above the recommended daily intake and, as a result, we used the X-ray powder diffraction technique as an analytical tool to evaluate the oxidation state of Chromium in such samples.

Keywords: Atomic absorption. Chromium. Manganese. Micronutrients. Supplements. X-ray diffraction.

\section{RE S U M O}

\section{Objetivo}

Neste trabalho, foram estudados diferentes tipos de suplementos esportivos contendo proteína de soro de leite, conhecidos como: whey protein, hipercalóricos e barras de proteína.

\section{Métodos}

Um procedimento de preparo de amostras foi estudado com o emprego de digestão úmida assistida por micro-ondas, a fim de determinar os teores de cromo e manganês por espectrometria de absorção atômica em forno de grafite.

\section{Resultados}

Os métodos adotados apresentaram boa exatidão (recuperações na faixa de 90 a 109\%) e precisão (Desvio padrão relativo <8\%). Embora tenha sido obtida uma capacidade de detecção adequada de 50 ng $g^{-1}$ para o manganês e de 65ng $\mathrm{g}^{-1}$ para o cromo, o método de preparo da amostra também se revelou adequado para a utilização em análises por espectrometria de massas com plasma indutivamente acoplado. O método foi aplicado a 26 amostras comerciais, cujas concentrações de cromo variaram entre 0,22 e 1,0 $\mathrm{gg} \mathrm{g}^{1}$, e de manganês entre 2,0 e $37 \mu g g^{-1}$.

\section{Conclusão}

Os resultados obtidos por absorção atômica, para ambos os analitos, mostraram-se de acordo com aqueles obtidos por espectrometria de massas. Além disso, algumas amostras apresentaram concentrações de cromo acima da recomendação de consumo diário e, como resultado, a técnica de difração de raios- $X$ em pó foi utilizada como ferramenta analítica para avaliar o estado de oxidação do cromo em tais amostras.

Palavras-chave: Absorção atômica. Cromo. Manganês. Micronutrientes. Suplemento. Difração de raios X.

\section{NTRODUCTION}

There is a current worldwide trend towards stereotyped beauty patterns and anti-aging solutions. The search of these aesthetic benefits is a concern that affects all age groups, regardless of gender or social class. Consequently, a significant increase in the consumption of dietary supplements has been observed [1-4].

Sport supplements are indicated for patients with deprived diets and for athletes looking for improvements in physical performance [5]. These products are formulated based on macro and micronutrients in different proportions, making them suitable for different purposes [6]. In this work, we debate the supplements based on Whey Proteins (WP), which have high nutritional value, presenting high levels of essential amino acids, calcium, and bioactive peptides [7].

Generally, dietary supplements may contain minerals in concentrations ranging from $\mathrm{mg} \mathrm{g}^{-1}$ to $\mu \mathrm{g} \mathrm{g}^{-1}$, (i.e. they contain both macro and micro minerals or trace elements) [8]. One of these 
minerals is Chromium ( $\mathrm{Cr}$ ), which draws one's attention as it naturally presents itself in two states of oxidation. While its trivalent form is considered essential for some metabolic processes of carbohydrates and lipids $[9,10]$, the hexavalent one is toxic, potentially carcinogenic, and therefore should not be consumed $[11,12]$. On its turn, trivalent Chromium potentiates the effects of insulin, improving glucose tolerance $[13,14]$. The importance of the glucose tolerance factor has stimulated the development of Chromium (III) supplements, such as Chromium picolinate, Chromium nicotinate, Chromium citrate, and Chromium amino acid complexes [15].

As for Manganese (Mn), it is an essential trace element and plays an important role in various metabolic processes in the human body, as a constituent of many enzymes and a co-factor in various enzymatic processes [16]. The regulation of blood sugar [17] also stands among its most relevant functions. Consequently, Manganese deficiency in the body has been reported as responsible for impairment and changes in lipid and carbohydrate metabolism [18].

Chromium and Manganese dispute the absorption sites in the intestine with other metals such as iron, zinc, and copper [19]. Chromium, Manganese, and iron also use the same carrier protein, transferrin, responsible for their distribution throughout the body. Therefore, an unbalanced diet might not only influence the deficiency of one micronutrient, but also of others. Health problems such as anemia or even diabetes are some examples, exerting effects on the growth and metabolism of lipids and proteins, respectively $[13,19]$.

In addition, some supplements may contain excessive doses of potentially toxic ingredients $[3,20]$, while others do not present the values stipulated by their nutritional tables $[21,22]$. Thus, there is a need for periodic evaluations of these products.

This work aimed to determine and evaluate the concentrations of Chromium and Manganese in sport supplements for athletes, prioritizing the products based on whey proteins. For this goal, Graphite Furnace Atomic Absorption Spectrometry (GF AAS) was used to determine the analytes, while the samples were prepared by Microwave-Assisted Wet Digestion (MAWD). All the procedures were optimized regarding accuracy and precision parameters, while the analytical results were compared with the ones obtained by Inductively Couplect Mass Spectrometry with Plasma Source (ICP-MS). The samples that presented high Chromium concentrations were also analyzed by X-ray powder Diffraction (XRD) and Electron Paramagnetic Resonance spectroscopy (EPR) techniques, which indicated the presence of hexavalent Chromium.

\section{METHODS}

All measurements were performed on an atomic absorption spectrometer with graphite furnace (Thermo Scientific Solaar Series M5, Waltham, USA) equipped with a background corrector (deuterium lamp). We used hollow-cathode lamps (Photron Lamps, USA) operating with a $6 \mathrm{~mA}$ maximum current, a bandpass of $0.5 \mathrm{nM}$, and a 357.9nM wavelength for $\mathrm{Cr}$, whereas for $\mathrm{Mn}$ the maximum current was $5 \mathrm{~mA}$, the bandpass was $0.2 \mathrm{nM}$, and the wavelength was of $279.5 \mathrm{nM}$. Pyrolytic coated graphite tubes were used and all injections were performed manually with the aid of a volumetric micropipette. Microwave-assisted wet digestion was carried out in a microwave oven Speed Wave 4 (Berghof, Germany) equipped with twelve high-pressure vials (DAP-30) of Teflon-Polytetrafluoroethylene (PTFE). All used reagents were of analytical grade. The solutions were prepared using deionized water (Elga Purelab Option-Q, model LA611, UK). Nitric acid (Sciavicco Comércio and Indústria Ltda, 65\% v/v) was also used for the preparation of samples 
and solutions. The standard solutions were prepared from the stock solution dilution of $1000 \mathrm{mg} \mathrm{L}^{-1}$ $\mathrm{Cr}$ (Vetec Química Fina Ltda) and Mn (Qhemis High Purity). All the used glassware was cleaned in a $10 \%(\mathrm{v} / \mathrm{V})$ nitric acid bath for 24 hours, then rinsed with deionized water at least three times, and dried at room temperature.

A total of 26 sport supplement samples were obtained, which may be subdivided into three types: whey protein supplements [15], supplements based on proteins and carbohydrates, known as "hypercaloric" [4], and samples of protein supplement in bars [7]. The whey protein samples are basically composed of concentrated, isolated, and/or hydrolyzed proteins with concentration ranging from $60 \%$ to $90 \%$. The hypercaloric samples are composed of carbohydrates ranging from $60 \%$ to $80 \%$, and proteins ranging from $10 \%$ to $30 \%$. The protein bar samples, on the other hand, vary in composition among different brands: some are added of dietary fiber (2\% to $30 \%)$, while most of them are mainly composed of carbohydrates (20\% to 50\%), proteins (30\% to $40 \%$ ), and lipids (10\% to $20 \%$ ).

All samples were packed in previously cleaned appropriate vials. The protein bar samples were crushed, taken into the oven (Odontobras EL 1.3 , Brazil) at $60^{\circ} \mathrm{C}$ for 48 hours, then pulverized with the aid of a pistil and agate mortar, and finally conditioned in previously cleaned appropriate vials.

For the determination of metals in sport supplements, the literature demonstrates the need for a preliminary stage of acid digestion by heating, with the purpose of reaching complete mineralization of the samples. Thus, the procedure used for the digestion of similar samples was adapted, but using microwave radiation [20] and also a heating program available in the microwave oven software (Berghof Applications 7.0). The established procedure consisted of weighting 250mg of the dried samples directly in the PTFE flasks, in which $6.0 \mathrm{~mL}$ of previously distilled nitric acid were added. This mixture was taken to the microwave digester following the preparation procedure where $1300 \mathrm{~W}$ of potency was applied for 6 minutes until reaching a temperature of $170^{\circ} \mathrm{C}$, which was maintained for 10 minutes. Next, $1300 \mathrm{~W}$ of power was applied again for 2 minutes until reaching the temperature of $210^{\circ} \mathrm{C}$, and the temperature was maintained for 15 minutes. After this procedure, the digested solutions were cooled to room temperature and diluted with deionized water to $25.00 \mathrm{~mL}$ in a volumetric flask.

For the determinations involving graphite furnace atomic absorption spectrometry, optimization of the instrumental conditions, such as chemical modifier, pyrolysis temperature, and atomization temperature, were performed. The optimization process for Chromium relied on univariate analysis and all measurements were performed in triplicate. Due to the time and instrumental resources available, the verification of optimal conditions for Manganese was conducted through a multivariate study using a factorial design $3^{2}$.

Matrix modifier was evaluated for the samples using a $12.75 \mu \mathrm{g}$ mass of $\mathrm{Mg}\left(\mathrm{NO}_{3}\right)_{2}$ in the volume injected into the tubes. After optimizing the usage conditions of the chemical modifier, the furnace program for $\mathrm{Cr}$ and $\mathrm{Mn}$ in samples of sports supplements was optimized and the optimal temperatures of pyrolysis and atomization were established. The total volume of solution placed in the furnace was $25 \mu \mathrm{L}(20 \mu \mathrm{L}$ when not using matrix modifier). Pyrolysis and atomization curves for $\mathrm{Cr}$ were investigated by varying the temperature in increments of $50^{\circ} \mathrm{C}$ in the range of $1000^{\circ} \mathrm{C}$ to $1200^{\circ} \mathrm{C}$ for the pyrolysis, while the increments were of $100^{\circ} \mathrm{C}$ in the range of 2000 to $2400^{\circ} \mathrm{C}$ for the atomization. For $\mathrm{Mn}$, the $3^{2}$ factorial design for the optimization of pyrolysis and atomization temperatures was investigated in the temperature range of $700^{\circ} \mathrm{C}$ to $1400^{\circ} \mathrm{C}$ and from $1800^{\circ} \mathrm{C}$ to $2500^{\circ} \mathrm{C}$, respectively. The results obtained throughout the heating programs optimized for $\mathrm{Cr}$ and $\mathrm{Mn}$ are shown in the Table 1. 
Table 1. Optimized instrumental conditions for the determination of $\mathrm{Cr}$ and $\mathrm{Mn}$ in samples of sports supplements by graphite furnace atomic absorption spectrometry. Juiz de Fora (MG), Brazil, 2016.

\begin{tabular}{lcccc}
\hline Step & Temperature $\left({ }^{\circ} \mathrm{C}\right)$ & Time $(\mathrm{s})$ & Ramp $\left({ }^{\circ} \mathrm{C} \mathrm{s}{ }^{-1}\right)$ & Gas flow rate $\left.(\mathrm{L} \mathrm{min})^{-1}\right)$ \\
\hline Drying & 100 & 30 & 10 & 0.2 \\
Pyrolysis & $900^{\mathbf{a}}, 1050^{\mathbf{b}}, 1100^{\mathbf{c}}$ & 25 & 150 & 0.2 \\
Atomization & $1950^{\mathbf{a}}, 2300^{\mathbf{b} \mathbf{c}}$ & 3 & 0 & 0.0 \\
Washing & 2600 & 3 & 0 & 0.3 \\
\hline
\end{tabular}

Note: ${ }^{\mathbf{D}}$ Determination of $\mathrm{Mn}$ in supplements; ${ }^{\mathbf{b}}$ Determination of $\mathrm{Cr}$ in bar protein supplements; ${ }^{\mathbf{c}}$ Determination of $\mathrm{Cr}$ in hypercaloric and whey protein type supplements.

min: Minutes; s: Seconds.

The method Limits of Detection (LOD) and Quantification (LOQ) were calculated by multiplying the value of the Standard Deviation (SD) (10 signal measurements of the blank digestions), by 3.3 or 10 (LOD and LOQ, respectively) [23]. The calculated SD were divided by the slopes of the analytical curves. Then, a correction factor was used considering the sample mass used in the method and in the final volume of the digested samples.

Regarding the method's detectability, the sensitivity was evaluated through the calculation of the characteristic mass $\left(m_{0}\right)$. The method's precision was verified using the Relative Standard Deviation (RSD). Spike tests were also performed in order to evaluate the accuracy in two levels of concentration. The analytes were added, as solutions, to the samples immediately after those had been weighted. For the first level, the $\mathrm{Cr}$ concentrations in the samples were of $2.5 \mu \mathrm{g} \mathrm{L}^{-1}$ and the $\mathrm{Mn}$ concentrations in the samples were, as follows: whey protein $\left(120 \mu \mathrm{g} \mathrm{L}^{-1}\right)$, hypercaloric $\left(45 \mu \mathrm{g} \mathrm{L}^{-1}\right)$, and protein bar $\left(70 \mu \mathrm{g} \mathrm{L}^{-1}\right)$. For the second level, the $\mathrm{Cr}$ concentrations in the samples were of $5.0 \mu \mathrm{g} \mathrm{L}^{-1}$ and the $\mathrm{Mn}$ concentrations in the samples were the following: whey protein (200 $\left.\mathrm{g} \mathrm{L}^{-1}\right)$, hypercaloric $\left(165 \mu \mathrm{g} \mathrm{L}^{-1}\right)$, and protein bar $\left(190 \mu \mathrm{g} \mathrm{L}^{-1}\right)$. The blank samples were also analyzed.

X-ray powder diffraction was used as an analytical tool to evaluate the state of Chromium oxidation in the samples. For this purpose, a comparison was made among the diffractograms of the supplement samples with those of Chromium (III) picolinate and Chromium trioxide (VI). The XRD analyses were performed on a Bruker diffractometer (D8 Advance Da Vinci model) with

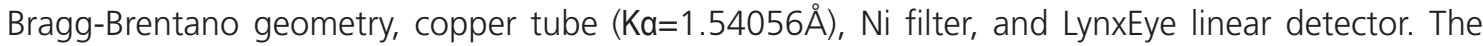
diffractograms were collected in the angular range of $5^{\circ}$ to $50^{\circ}$ with a pitch of $0.02^{\circ}$ and a $0.6 \mathrm{~mm}$ divergence slit, and primary and secondary $2.5^{\circ}$ Soller slits. The working conditions were $40 \mathrm{kV}$ voltage and $40 \mathrm{~mA}$ current.

\section{RESULTS AND DISCUSSION}

For the determination of $\mathrm{Cr}$ in the studied samples, we used $12.75 \mu \mathrm{g}$ of $\mathrm{Mg}\left(\mathrm{NO}_{3}\right)_{2}$ together with the injection of each sample into the graphite furnace. It was not necessary to use a chemical modifier for the determination of $\mathrm{Mn}$.

To evaluate the need of a chemical modifier for Chromium, analytical determinations were performed in the samples of sports supplement with and without the addition of the modifier. The mean absorbance with the modifier ranged from $(0.108 \pm 0.007)$ for protein bar samples, $(0.231 \pm 0.003)$ for whey protein samples, and $(0.114 \pm 0.004)$ for hypercaloric samples, while without the chemical modifier it varied between $(0.081 \pm 0.004),(0.189 \pm 0.009)$, and $(0.089 \pm 0.005)$, respectively. The variance in these results was evaluated through the $F$ test, being comparable ( $F_{\text {calculated }} 1.55$ and $F_{\text {critical }}$ 3.44). The averages were compared through paired Student's $t$-test, $t$ calculated of 9.03 and $t$ critical 
of 4.30. This indicates that these values are not equivalent. Therefore, the use of $\mathrm{Mg}\left(\mathrm{NO}_{3}\right)_{2}$ favors the increase of the analytical signal.

Although the use of chemical modifiers may be unnecessary for the determination of Chromium due to its refractory behavior, the use of relatively low pyrolysis temperatures can influence the elimination of complex matrices [24-26]. The use of modifiers such as magnesium nitrate, $\mathrm{Mg}\left(\mathrm{NO}_{3}\right)_{2}$, is reported in the literature for Chromium determination in different types of matrices, allowing the thermal stabilization of the analyte during the pyrolysis step without sensitivity losses, thus justifying its use $[25,26]$.

For Chromium, the optimization of pyrolysis and atomization temperatures was performed in a univariate analysis and using $\mathrm{Mg}\left(\mathrm{NO}_{3}\right)_{2}$ as a chemical modifier. In this case, the pyrolysis temperature varied from $1000^{\circ} \mathrm{C}$ to $1200^{\circ} \mathrm{C}$. Once the optimum pyrolysis temperatures were found and defined for the different types of samples, a similar procedure ensued by varying the atomization temperature, evaluated for the range of $2000^{\circ} \mathrm{C}$ to $2400^{\circ} \mathrm{C}$ in order to observe at which temperature one could obtain the best sensitivity. Figure 1A shows the pyrolysis and atomization curves for $\mathrm{Cr}$ determination in whey protein, hypercaloric, and protein samples. As seen in Figure 1B, the response surface for optimizing pyrolysis and atomization temperatures indicated that the $\mathrm{Mn}$ atomization temperature does not influence the analytical sensitivity and, therefore, this was set at $1950^{\circ} \mathrm{C}$, since lower temperatures increase the graphite tube's lifespan. Regarding the pyrolysis temperature, the different types of samples presented higher sensitivity at $900^{\circ} \mathrm{C}$.

A

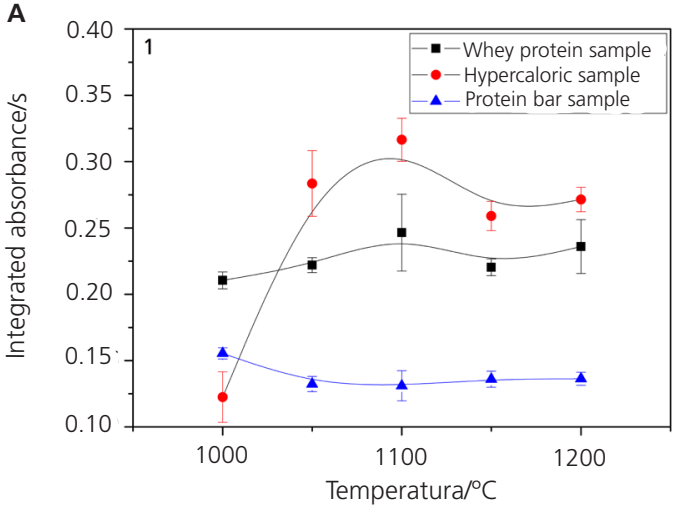

B

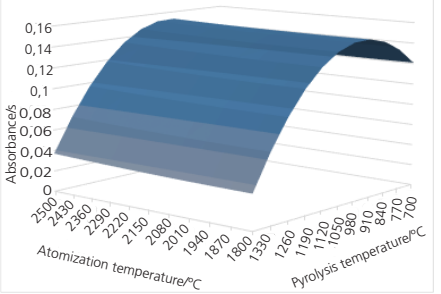

4

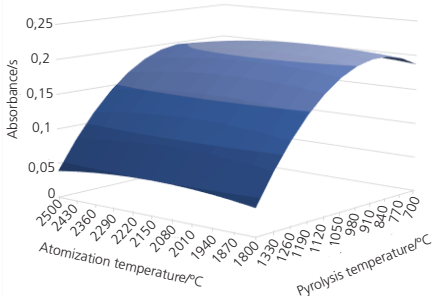

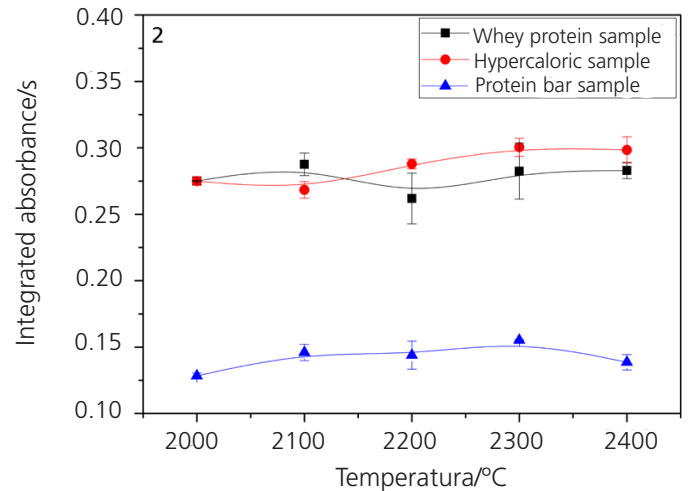

5

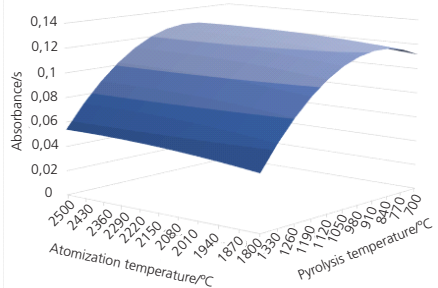

Figure 1. Studies of: Figures: $\mathrm{A} 1$ : Pyrolysis conducted in the range of $1000^{\circ} \mathrm{C}$ to $1200^{\circ} \mathrm{C}$; and, $\mathrm{A} 2$ atomization conducted in the range of $2000^{\circ} \mathrm{C}$ to $2400^{\circ} \mathrm{C}$. Figures B: Response surface for optimizing pyrolysis and atomization temperatures for manganese determination in samples of: B3: Whey Protein; B4: Hypercaloric; and, B5: Protein Bar. Juiz de Fora (MG), Brazil, 2016.

Note: The chemical modifier used to Chromium determination was $12.75 \mu \mathrm{g}$ of $\mathrm{Mg}\left(\mathrm{NO}_{3}\right)_{2}$. Response surface analysis of variance: $(A) F_{\mathrm{faj}}=0.67$, $F_{\text {reg }}=36.5 ;(B) F_{\text {faj }}=0.68, F_{\text {reg }}=92.6$; and, (C) $F_{\text {faj }}=0.66, F_{\text {reg }}=121.4 . F_{\text {faj }}$-crit=19.2 and $F_{\text {reg-crit }}=5.05 . F_{\text {faj }}$ : Lack-of-fit $F$-test. $F_{\text {reg: }}$ : Regression $F$-test. $F_{\text {faj }}$-crit: Lack-of-fit F-test critical. Freg: Regression F-test critical. 
The results obtained (Table 1) are in agreement with the scientific literature for Chromium and Manganese determination using GF AAS. Pyrolysis and atomization temperature for the determination of Chromium in multivitamin supplement samples, food samples of plant origin, and infant formula samples were employed in the range of $1100^{\circ} \mathrm{C}$ to $1400^{\circ} \mathrm{C}$ and from $2300^{\circ} \mathrm{C}$ to $2550^{\circ} \mathrm{C}$, respectively $[3,27,28]$. On the other hand, Manganese was determined employing 1200 and $2000^{\circ} \mathrm{C}$ for pyrolysis and atomization temperature of multivitamin supplement samples [3].

For the evaluation of these analytical parameters, the external curve calibration method was used with the added chemical modifier. The concentrations of the standard solutions used to plot the analytical curve ranged from 2.25 to $11.75 \mu \mathrm{L} \mathrm{L}^{-1}$ to $\mathrm{Cr}(\mathrm{y}=0,0489 \mathrm{x}+0,1176$ and $\mathrm{y}=0,0466 \mathrm{x}+0,1508$, linear equations for determination in protein bar samples and hypercaloric ones, and also whey protein samples, respectively) and from 1 to $10 \mu \mathrm{g} \mathrm{L}^{-1}$ to $\mathrm{Mn}(\mathrm{y}=0,0283 \mathrm{x}+0,0188)$. The models were evaluated through an analysis of variance, in which there is no indication of lack of fit, for a $95 \%$ confidence level.

Analytical precision was evaluated through the Relative Standard Deviation (RSD) of the analyzed replicates. The RSD remained evidently below $8 \%$ for all analyses, which is indicative of good analytical precision, not only considering the analytes level, but also that the samples were injected manually.

Accuracy in sports supplements was assessed by spike tests. It should be noted that the standard solution was added to the samples prior to the digestion process and that a fortified blank sample was also prepared. The recovery values obtained were: $103.0 \%, 101.5 \%$, and $98.5 \%$ for $\mathrm{Cr}$ recovery in whey protein, hypercaloric, and protein bar samples, respectively; and $109.0 \%, 102.0 \%$, and $105.5 \%$ for $\mathrm{Mn}$ recovery in the same samples. These values indicated that errors related to analyses under optimized conditions were small and that the method shows good accuracy. Digested blank samples were also evaluated and recovery values ranged from $90.0 \%$ to $102.5 \%$. In general, the recovery of metals satisfied requisites reported in the Decision 2002/657/EC that accepted a recovery bias between $-50 \%$ and $+20 \%$ for the concentration level of the samples, approximately $0.5 \mu \mathrm{g} \mathrm{g}^{-1}[29]$.

In graphite furnace atomic absorption spectrometry determinations, the detectability is called "analytical sensitivity" and this parameter is expressed in terms of mass, referred to as "characteristic mass" $\left(m_{0}\right)$. This value corresponds to the mass of the analyte responsible for absorbing $1 \%$ of the radiation, in picograms (pg) $[25,30,31]$. The characteristic mass of Chromium in the sports supplement samples ranged from 2.7 to $2.8 \mathrm{pg}$, which is in agreement with the value of $3 \mathrm{pg}$ reported for longitudinally heated atomizers. For Manganese, the values ranged from 2.2 to $2.6 \mathrm{pg}$, which is also satisfactory when compared to the literature data $(2 \mathrm{pg})$. This demonstrates that the method also shows good sensitivity [32].

For Chromium, the obtained LOD ranged from 43ng g-1 (protein bar) to 65ng g-1 (whey protein); as for Manganese, the value was $50 \mathrm{ng} \mathrm{g}^{-1}$ for the different types of supplements. In relation to the LOQ, the lowest analyte concentration that can be quantified with acceptable accuracy and precision, the value obtained for Manganese was $160 \mathrm{ng} \mathrm{g}^{-1}$, while for Chromium the values ranged from $145 \mathrm{ng} \mathrm{g}^{-1}$ (protein bar) to $218 \mathrm{ng} \mathrm{g}^{-1}$ (whey protein). After validating the method and obtaining the figures of merit, 26 different samples were collected and analyzed. The results are in Table 2.

We evaluated the presence of Chromium and Manganese in fifteen samples of the analyzed supplements of whey protein type, as well as the presence of these analytes in products that not 
Table 2. Results for determination of chromium and manganese in sports supplement samples analyzed by graphite furnace atomic absorption spectrometry. Juiz de Fora (MG), Brazil, 2016.

\begin{tabular}{|c|c|c|}
\hline Samples & Chromium $\left(\mu \mathrm{g} \mathrm{g}^{-1}\right)$ & Manganese $\left(\mu g^{-1}\right)$ \\
\hline WP1 & $(1.04 \pm 0.14)$ & $(5.40 \pm 0.43)$ \\
\hline WP2 & $(0.22 \pm 0.06)$ & $(33.20 \pm 1.10)$ \\
\hline WP3 & $<0.07$ & $(5.07 \pm 0.59)$ \\
\hline WP4 & $<0.22$ & $(5.77 \pm 0.07)$ \\
\hline WP5 & $<0.22$ & $(30.80 \pm 1.40)$ \\
\hline WP6 & $(0.89 \pm 0.06)$ & $(4.88 \pm 0.10)$ \\
\hline WP7 & $(0.79 \pm 0.14)$ & $(6.31 \pm 0.58)$ \\
\hline WP8 & $(0.44 \pm 0.10)$ & $(19.10 \pm 0.60)$ \\
\hline WP9 & $(0.31 \pm 0.08)$ & $(2.00 \pm 0.04)$ \\
\hline WP10 & $<0.22$ & $(7.01 \pm 0.13)$ \\
\hline WP11 & $<0.22$ & $(36.40 \pm 0.50)$ \\
\hline WP12 & $<0.07$ & $(3.95 \pm 0.24)$ \\
\hline WP13 & $<0.22$ & $(37.40 \pm 3.20)$ \\
\hline WP14 & $(0.29 \pm 0.09)$ & $(14.30 \pm 1.30)$ \\
\hline WP15 & $(0.26 \pm 0.07)$ & $(5.59 \pm 0.22)$ \\
\hline $\mathrm{HC} 1$ & $(0.30 \pm 0.07)$ & $(11.10 \pm 1.20)$ \\
\hline $\mathrm{HC} 2$ & $(0.44 \pm 0.05)$ & $(8.60 \pm 0.58)$ \\
\hline $\mathrm{HC} 3$ & $(0.27 \pm 0.08)$ & $(4.95 \pm 0.23)$ \\
\hline $\mathrm{HC} 4$ & $<0.15$ & $(7.16 \pm 0.11)$ \\
\hline PB1 & $(0.63 \pm 0.06)$ & $(12.70 \pm 0.10)$ \\
\hline PB2 & $(0.54 \pm 0.07)$ & $(14.90 \pm 0.90)$ \\
\hline PB3 & $(0.41 \pm 0.07)$ & $(14.80 \pm 1.50)$ \\
\hline PB4 & $(0.40 \pm 0.06)$ & $(19.30 \pm 1.20)$ \\
\hline PB5 & $(0.65 \pm 0.04)$ & $(26.00 \pm 1.60)$ \\
\hline PB6 & $(0.41 \pm 0.02)$ & $(18.30 \pm 1.60)$ \\
\hline PB7 & $(0.56 \pm 0.05)$ & $(16.80 \pm 0.80)$ \\
\hline
\end{tabular}

Note: HC: Supplements of the Hypercaloric Type; PB: Protein Bar Supplements; WP: Whey Protein Supplements.

always inform the Chromium content in their labels. Seven samples had concentrations below the limits of quantification for Chromium, and the others varied in the range of $0.22 \mathrm{~g}^{-1}$ to $1.04 \mu \mathrm{g} \mathrm{g}^{-1}$. We were able to quantify Manganese in the fifteen samples and its concentration ranged from $2.00 \mathrm{~g}^{-1}$ to $37.4 \mu \mathrm{g} \mathrm{g}^{-1}$.

Based on the information found on the products labels, we calculated the percentage of the Recommended Daily Intake (RDI) the consumption of one dose of these products can supply. For Chromium, one single dose can supply from $19 \%$ to $229 \%$ of the RDI, considering the experimentally found Chromium levels. It is noteworthy that three of the analyzed samples (WP1, WP6, and WP9) presented values of the RDI supplied above $100 \%$, which may be nutritionally inadequate. With respect to Manganese, all samples presented RDI below 100\%, except the sample WP5 (134\%).

Chromium was detected in the three of the four hypercaloric samples, with its concentrations ranging from $0.27 \mathrm{~g}^{-1}$ to $0.44 \mu \mathrm{g} \mathrm{g}^{-1}$. The values found can supply $61 \%$ to $161 \%$ of the Chromium RDI, with Hypercaloric sample number 2 (HC2) and Hypercaloric sample number 3 ( $\mathrm{HC} 3$ ) offering contributions above 100\%. Manganese levels were determined for all the four samples, with its concentration ranging from $4.95 \mathrm{~g}^{-1}$ to $11.1 \mu \mathrm{g} \mathrm{g}^{-1}$. Considering the manufacturers' recommended intake rates for the samples evaluated, this element does not provide values greater than $100 \%$. 
For protein bar samples, Chromium concentrations ranged from $0.40 \mathrm{~g}^{-1}$ to $0.65 \mu \mathrm{gg} \mathrm{g}^{-1}$. The RDI values provided by the consumption of one supplement dose ranged from $35 \%$ to $83 \%$. Manganese concentrations ranged from 12.7 to $26 \mu^{-1} g^{-1}$, corresponding to $18 \%$ to $51 \%$ of the RDI.

In this context, the samples were analyzed for the statistical comparison of results and thus to confirm the accuracy of the proposed methods using Inductively Coupled Plasma Mass Spectrometry (ICP-MS).

The results were statistically compared and the variances in concentration levels were evaluated using the F-test. We consider the variances for both micronutrients equivalent, since the calculated $F$ value (1.08 and 1.07 for $\mathrm{Cr}$ and $\mathrm{Mn}$, respectively) is less than the critical $F$ (6.39). The statistical comparison of the concentration averages obtained through the different techniques was performed using a Student paired $t$-test, where the value obtained for $t$ calculated for Chromium and Manganese concentrations ( 0.06 and 0.35 , respectively) was lower than the critical $t$ value (2.78). Therefore, with $95 \%$ confidence, there are no assumptions that indicate significant differences between the results obtained by ICP-MS and the results obtained by the GF AAS method.

Considering this work's results, it can be stated that GF AAS is an interesting alternative in relation to ICP-MS and Inductively Coupled Plasma Optical Emission Spectrometry (ICP OES) techniques for Chromium and Manganese monitoring in supplements samples. These results are also important information that can be used to establish criteria to control the access to whey protein based supplements, since consumption rates are increasing significantly in recent years [3]. The limits of detection obtained (Chart 1) are in the same order of magnitude of the ones reported in the literature. Minor variations may be considered normal since different sample preparation methods are used in these works.

Considering that the concentration values obtained were significantly higher than those reported by the manufacturers, X-ray powder diffraction was used as a tool to identify the chemical form of Chromium in such samples, that is, if there is $\mathrm{Cr}^{\mathrm{II}}$ or $\mathrm{Cr}^{\mathrm{v}}$, or even a mixture of crystalline phases with both compositions.

Chart 1. Comparison of the method developed by graphite furnace atomic absorption spectrometry with others methods available in the literature. Juiz de Fora (MG), Brazil, 2016.

\begin{tabular}{lclcc}
\hline LOD $(\mathrm{Cr})$ & LOD $(\mathrm{Mn})$ & \multicolumn{1}{c}{ Sample } & Technique & Reference \\
\hline $65 \mathrm{ng} \mathrm{g}^{-1}$ & $50 \mathrm{ng} \mathrm{g}^{-1}$ & Whey protein, hypercaloric and protein bar & GF AAS & This work \\
$2 \mathrm{ng} \mathrm{g}^{-1}$ & $1 \mathrm{ng} \mathrm{g}^{-1}$ & Multivitamin supplements & HR-CS GF AAS & {$[3]$} \\
$20 \mu \mathrm{g} \mathrm{g}^{-1}$ & $2 \mu \mathrm{g} \mathrm{g}^{-1}$ & Dietary supplement formulations based on edible mushrooms & GF AAS & {$[33]$} \\
$0.4 \mathrm{~g} \mathrm{~g}^{-1}$ & $6 \mu \mathrm{g} \mathrm{g}^{-1}$ & Nutritional supplements & ICP-MS and ICP OES & {$[8]$} \\
$1.4 \mathrm{ng} \mathrm{g}^{-1}$ & $16 \mathrm{ng} \mathrm{g}^{-1}$ & Botanicals and dietary supplements & ICP-MS & {$[34]$} \\
$0.9 \mathrm{ng} \mathrm{g}^{-1}$ & $1 \mathrm{ng} \mathrm{g}^{-1}$ & Multivitamin and multi-mineral preparations & ICP-MS & {$[35]$} \\
$12 \mathrm{ng} \mathrm{g}^{-1}$ & - & Infant formula & SS-HR-CS ET AAS & {$[36]$} \\
$87 \mathrm{ng} \mathrm{g}^{-1}$ & - & Plant samples & GF AAS & {$[27]$} \\
$0.1 \mathrm{Mg} \mathrm{g}^{-1}$ & - & Dietary supplements & GF AAS & {$[37]$} \\
$6 \mu \mathrm{g} \mathrm{g}^{-1}$ & - & Food supplement of herbal origin & ICP-MS & {$[38]$} \\
\hline
\end{tabular}

Note: GF AAS: Graphite furnace atomic absorption spectrometry; HR-CS GF AAS: High-Resolution Continuum Source Graphite Furnace Atomic Absorption Spectrometry; ICP-MS: Inductively Coupled Plasma Mass Spectrometry; ICP OES: Inductively Coupled Plasma Optical Emission Spectrometry; SS-HR-CS ET AAS: High-Resolution Continuum Source Electrothermal Atomic Absorption Spectrometry combined with the Solid Sample analysis. 
This study consisted in obtaining the diffractograms of selected samples in the angular range of $5 \%$ to $50^{\circ}$ (a region that concentrates the diffraction peaks with higher intensities) and comparison with the diffractograms of the Chromium trioxide (VI), $\mathrm{CrO}_{3}$, and Chromium Picolinate(III), $\mathrm{Cr}\left(\mathrm{C}_{6} \mathrm{H}_{4} \mathrm{NO}_{2}\right)_{3}$. Some of the obtained diffractograms are presented in Figure 2.

Evaluating the diffractograms, peaks were observed in the different samples at angles characteristic of Chromium Picolinate $\left(18.1^{\circ}, 19.2^{\circ}\right.$, and $\left.28.6^{\circ}\right)$. However, some peaks possibly correspond to the contribution of both investigated Chromium compounds; peaks at $20.8^{\circ}$ should correspond to Chromium picolinate and $\mathrm{CrO}_{3}$ simultaneously. The most worrisome evidence is related to the fact that peaks at angles of $21.2^{\circ}, 26.4^{\circ}$, and $37.6^{\circ}$ can be attributed to $\mathrm{CrO}_{3}$. Using XRD as an analytical tool, there is evidence of Chromium in the oxidation states of $\mathrm{Cr}^{\mathrm{III}}$ and $\mathrm{Cr}^{\mathrm{VI}}$ in some of the samples studied.

It is important to highlight that sports supplements are complex samples, which present other constituents that have diffraction patterns. The diffractogram of Lactose, for example, displays some peaks of good intensity at angles close to those observed in the analysis, making it difficult to interpret the data collected. Thus, the samples were also evaluated by electronic
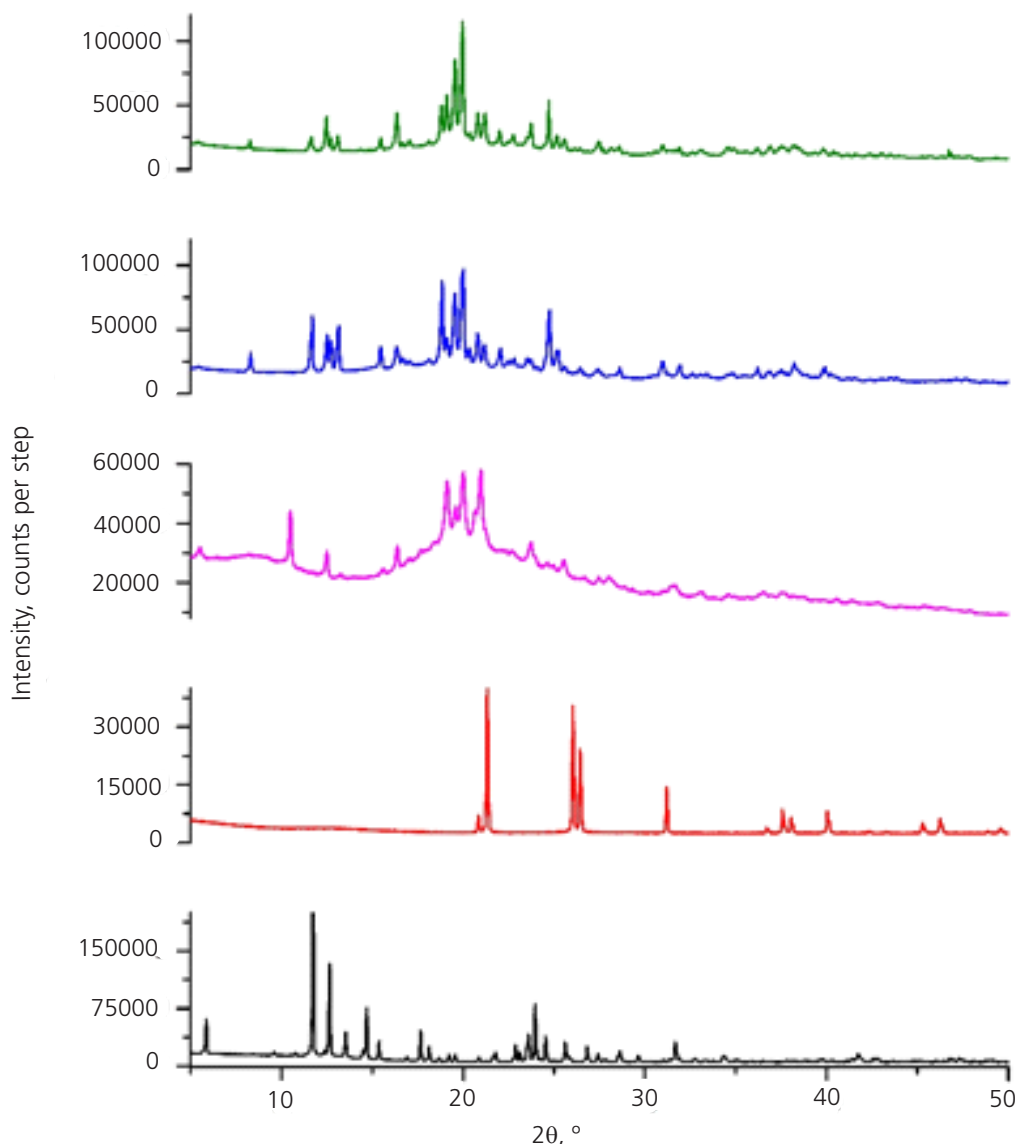

Figure 2. Diffractograms for sports supplement samples, Chromium(III) picolinate, and Chromium trioxide standards. Juiz de Fora, (MG), Brazil, 2016.

Note: Reading: Black: Chromium (III) Picolinate; Red: Chromium Trioxide; Pink: Whey Protein sample 7; Blue: Supplements of the Hypercaloric Type, sample 2; Green: Supplements of the Hypercaloric Type, sample 1. 
paramagnetic resonance spectroscopy in order to confirm the presence of Chromium in its toxic oxidation state.

The same samples evaluated by XRD were evaluated using Electron Paramagnetic Resonance Spectroscopy. Considering the levels of Chromium presented in the samples and the instrumental conditions used during the analyses, we could not obtain information on the oxidation number of the element in the samples evaluated.

\section{CONCLUSION}

Since the consumption of sports supplements has been increasing, an effective quality control for these products is essential, which includes the monitoring of their mineral contents. In this sense, since the results obtained by GF AAS and ICP-MS were statistically comparable, GF AAS can be defined as an adequate technique for the analysis, since it has lower instrumental and operational cost, which justifies its use for monitoring mineral micronutrients.

In this work, the evaluation of Chromium and Manganese in sports supplements samples showed high mineral concentrations, mainly of Chromium, which extrapolate the daily necessities. In a set of 26 samples, Chromium concentrations ranged from 0.22 to $1.0 \mu g^{-1}$, while Manganese ones ranged from 2.00 to $37.4 \mu \mathrm{g} \mathrm{g}^{-1}$.

The high levels of Chromium are even more worrisome from the results obtained by XRD, which corroborate with evidence of the $\mathrm{Cr}^{\mathrm{vl}}$ presence in some of the samples studied. Although inconclusive, the studies conducted by EPR are being optimized and the publication of such results is a future perspective.

\section{A C KNOWLEDGMENT}

We thank Dr. Fábio Ferreira da Silva and Agilent Technologies for the assistance during the execution of the analyses by ICP-MS and agencies Coordenação de Aperfeiçoamento de Pessoal de Nível Superior (CAPES, Coordination for the Improvenent of Higher Education Personnel), Conselho Nacional de Desenvolvimento Científico e Tecnológico (CNPq, National Council for Scientific and Technological Development), and Fundação de Amparo à Pesquisa do Estado de Minas Gerais (FAPEMIG, Research Support Foundation of the Minas Gerais State, Process CEX-APQ-02056-14) for the financial support The authors also thank Dr. Klaus Wilhelm Heinrick Krambrock and Universidade Federal de Minas Gerais (UFMG, Federal University of Minas Gerais) for their technical assistance in the analyses by EPR.

\section{CONTRIBUTORS}

LS FLORES and CC CORREA were responsible for X-ray powder diffraction analysis. TP LISBOA and RA SOUSA were responsible for the sample preparation procedure and analytical validation processes involving the determination of Chromium and Manganese.

\section{RE FERENCES}

1. Cerezo AB, Leal Á, Álvarez-Fernández MA, Hornedo-Ortega R, Troncoso AM, García-Parrilla MC. Quality control and determination of melatonin in food supplements. J Food Compost Anal. 2016;45:80-6. 
2. Abdelraheem EMH, Hassan SM, Arief MMH, Mohammad SG. Validation of quantitative method for azoxystrobin residues in green beans and peas. Food Chem. 2015;182:246-50.

3. Krawczyk M. Determination of macro and trace elements in multivitamin dietary supplements by high-resolution continuum source graphite furnace atomic absorption spectrometry with slurry sampling. J Pharm Biomed Anal. 2014;88:377-84.

4. Hartmann C, Siegrist M. Benefit beliefs about protein supplements: a comparative study of users and non-users. Appetite. 2016;103:229-35.

5. Alves C, Lima RVB. Dietary supplement use by adolescents. J Pediatr. 2009;85(4):8.

6. Almeida MR, Souza LP, Cesar RS, Sousa RA, Izumi CMS. Investigation of sport supplements quality by Raman spectroscopy and principal component analysis. Vib Spectrosc. 2016;87:1-7.

7. Milani PG, Dacome AS, Nalesso CCF, Fiorenti CA, Costa CEM, Costa SC. Functional properties and sensory testing of whey protein concentrate sweetened with rebaudioside A. Rev Nutr. 2016;29(1):125-37. http:// dx.doi.org/10.1590/1678-98652016000100012

8. Tokalığlu Ş, Clough R, Foulkes M, Worsfold P. Bioaccessibility of Cr, Cu, Fe, Mg, Mn, Mo, Se and Zn from nutritional supplements by the unified BARGE method. Food Chem. 2014;150:321-7.

9. Shinde UA, Sharma G, Xu YJ, Dhalla NS, Goyal RK. Insulin sensitising action of chromium picolinate in various experimental models of diabetes mellitus. J Trace Elem Med Biol. 2004;18(1):23-32.

10. Yao L, Zhu Y, Xu W, Wang H, Wang X, Zhang J, et al. Combination of dispersive solid phase extraction with dispersive liquid-liquid microextraction for the sequential speciation and preconcentration of $\mathrm{Cr}(\mathrm{III})$ and $\mathrm{Cr}(\mathrm{VI})$ in water samples prior to graphite furnace atomic absorption spectrometry determination. J Ind Eng Chem. 2019;72:189-95.

11. Sun H, Brocato J, Costa M. Oral chromium exposure and toxicity. Curr Environ Health Rep. 2015;2(3):295-303.

12. Andrade JK, Andrade CK, Felsner ML, Anjos VE. Ultrasound-assisted emulsification microextraction combined with graphite furnace atomic absorption spectrometry for the chromium speciation in water samples. Talanta. 2019;191:94-102.

13. Costello RB, Dwyer JT, Bailey RL. Chromium supplements for glycemic control in type 2 diabetes: limited evidence of effectiveness. Nutr Rev. 2016;74(7):455-68.

14. Nussbaumerova B, Rosolova H, Krizek M, Sefrna F, Racek J, Müller L, et al. Chromium supplementation reduces resting heart rate in patients with metabolic syndrome and impaired glucose tolerance. Biol Trace Elem Res. 2018;183(2):192-9.

15. Pham THN, Aitken JB, Levina A, Lay PA. Solid-state structural studies of chromium(III) nicotinate nutritional supplements. Inorg Chem. 2014;53(19):10685-94.

16. Bouabid S, Tinakoua A, Lakhdar-Ghazal N, Benazzouz A. Manganese neurotoxicity: behavioral disorders associated with dysfunctions in the basal ganglia and neurochemical transmission. J Neurochem. 2016;136(4):677-91

17. Du S, Wu X, Han T, Duan W, Liu L, Qi J, et al. Dietary manganese and type 2 diabetes mellitus: two prospective cohort studies in China. Diabetologia. 2018;61(9):1985-95.

18. Horning KJ, Caito SW, Tipps KG, Bowman AB, Aschner M. Manganese is essential for neuronal health. Annu Rev Nutr. 2015;35(1):71-108.

19. Bjørklund G, Aaseth J, Skalny AV, Suliburska J, Skalnaya MG, Nikonorov AA, et al. Interactions of iron with manganese, zinc, chromium, and selenium as related to prophylaxis and treatment of iron deficiency. J Trace Elem Med Biol. 2017;41:41-53.

20. Marrero J, Rebagliati RJ, Leiva E, Londonio A, Smichowski P. Inductively coupled plasma optical emission spectrometric determination of fifteen elements in dietary supplements: are the concentrations declared in the labels accurate? Microchem J. 2013;108:81-6.

21. Pereira RM, Crizel MG, Novo DLR, Santos CMM, Mesko MF. Multitechnique determination of metals and non-metals in sports supplements after microwave-assisted digestion using diluted acid. Microchem J. 2019;145:235-41.

22. Garrido BC, Souza GHMF, Lourenço DC, Fasciotti M. Proteomics in quality control: whey protein-based supplements. J Proteom. 2016;147:48-55. 
23. Agência Nacional de Vigilância Sanitária (Brasil). Resolução da Diretoria Colegiada n. 166: dispõe sobre a validação de métodos analíticos e dá outras providências. Brasília: Agência; 2017.

24. Almeida JS, Brandão GC, Santos GL, Teixeira LSG. Fast sequential determination of manganese and chromium in vegetable oil and biodiesel samples by high-resolution continuum source graphite furnace atomic absorption spectrometry. Anal Methods. 2016;8(15):3249-54.

25. Borges AR, François LL, Becker EM, Vale MGR, Welz B. Method development for the determination of chromium and thallium in fertilizer samples using graphite furnace atomic absorption spectrometry and direct solid sample analysis. Microchem J. 2015;119:169-75.

26. Zhong W-S, Ren T, Zhao L-J. Determination of Pb (Lead), Cd (Cadmium), Cr (Chromium), Cu (Copper), and $\mathrm{Ni}$ (Nickel) in Chinese tea with high-resolution continuum source graphite furnace atomic absorption spectrometry. J Food Drug Anal. 2016;24(1):46-55.

27. Dobrowolski R, Pawlowska-Kapusta I, Dobrzynska J. Chromium determination in food by slurry sampling graphite furnace atomic absorption spectrometry using classical and permanent modifiers. Food Chem. 2012;132(1):597-602.

28. Sola-Larrañaga C, Navarro-Blasco I. Chromium content in different kinds of Spanish infant formulae and estimation of dietary intake by infants fed on reconstituted powder formulae. Food Addit Contam. 2006;23(11):1157-68.

29. Commission Decision of 12 August 2002 implementing Council Directive 96/23/EC concerning the performance of analytical methods and the interpretation of results. Brussels: Official Journal of the European Communities; 2002.

30. Pozzatti M, Borges AR, Dessuy MB, Vale MGR, Welz B. Determination of cadmium, chromium and copper in vegetables of the Solanaceae family using high-resolution continuum source graphite furnace atomic absorption spectrometry and direct solid sample analysis. Anal Methods. 2017;9(2):329-37.

31. Passos AS, Tonon GF, Nakadi FV, Mangrich AS, Andrade JB, Welz B, et al. Determination of $\mathrm{Cr}$, Cu and Pb in industrial waste of oil shale using high-resolution continuum source graphite furnace atomic absorption spectrometry and direct solid sample analysis. Anal Methods. 2018;10(29):3645-53.

32. Welz B, Sperling M. Atomic absorption spectrometry. 3rd ed. Weinheim: Wiley-VCH; 1999.

33. Stilinović N, Škrbić B, Živančev J, Mrmoš N, Pavlović N, Vukmirović S. The level of elements and antioxidant activity of commercial dietary supplement formulations based on edible mushrooms. Food Funct. 2014;5(12):3170-8.

34. Avula B, Wang Y-H, Smillie TJ, Duzgoren-Aydin NS, Khan IA. Quantitative determination of multiple elements in botanicals and dietary supplements using ICP-MS. J Agri Food Chem. 2010;58(16):8887-94.

35. Krejčová A, Ludvíková I, Černohorský T, Pouzar M. Elemental analysis of nutritional preparations by inductively coupled plasma mass and optical emission spectrometry. Food Chem. 2012;132(1):588-96.

36. Silva AS, Brandao GC, Matos GD, Ferreira SLC. Direct determination of chromium in infant formulas employing high-resolution continuum source electrothermal atomic absorption spectrometry and solid sample analysis. Talanta. 2015;144:39-43.

37. Korfali SI, Hawi T, Mroueh M. Evaluation of heavy metals content in dietary supplements in Lebanon. Chem Cent J. 2013;7(1):10.

38. Brizio P, Benedetto A, Squadrone S, Tarasco R, Gavinelli S, Pellegrino M, et al. Heavy metals occurrence in Italian food supplements. Proceedings of the 16th International Conference on Heavy Metals in the Environment; 2012 Sep 23-27; Rome, Italy. Les Ulis: E3S Web of Conferences; 2013. http://dx.doi.org/10.10 51/e3sconf/20130115006 